\title{
Study on Trichoderma Citrinoviride 31/4 - Antagonistic Activity and Jasmonic Acid
}

\author{
Ariunjargal Jargalsaikhan, Temuujin Janchiv, Gantuya Myagmarsaikhan, Esentaish Gantsolmon, \\ and Otgonjargal Khureldagva
}

\begin{abstract}
The genus Trichoderma was first identified by the German scientist Persoon in 1974, and there are currently 89 species in the genus. Trichoderma fungi often break down organic compounds in the soil into minerals and plays an important role in soil fertility formation.

Trichoderma citrinoviride 31/4 isolated from the soil forms a colony with light yellow-green mycelium on the surface of the PDA medium, with spherical spore, septate hyphae, branched conidophores.

Trichoderma citrinoviride $31 / 4$ had antagonistic activity of 66.7\% against Cladosporium fulvum, $77.5 \%$ against Alternaria alternata, and 59.1\% against Fusarium oxysporium after 7 days.

Experimental results showed that the progress of tomato alternariosis treated with Trichoderma citrinoviride 31/4 was neutralized from the 7th day, and the biological activity was averagely $74 \%$ on the 21 st day.

Trichoderma citrinoviride $31 / 4$ contains $0.0135 \mathrm{mg} / \mathrm{kg}$ of jasmonic acid in plants treated with $10^{9}$ cell $/ \mathrm{ml}$ and $0.0076 \mathrm{mg} / \mathrm{kg}$ in plants treated with $10^{8} \mathrm{cell} / \mathrm{ml}$.
\end{abstract}

Index Terms - fungi, Alternaria alternata, biological activity, tomato.

\section{INTRODUCTION}

Trichoderma is a common fungus in the soil of the genus Hypocreaceae. Trichoderma fungal species differ from each other in their characteristics such as growth, colonic growth, conidia and conidophores, and branching. The genus Trichoderma was first identified by German scientist Persoon in 1974, and there are currently 89 species in the genus. Trichoderma fungi often break down organic compounds in the soil into minerals and plays an important role in soil fertility formation. It grows at $25-30{ }^{\circ} \mathrm{C}$, but for some species it grows at temperatures up to $45^{\circ} \mathrm{C}$. The PDA medium usually produces green micelles within a week, and some species produce slightly yellowish mycelium. Trichoderma produces the enzymes chitinase and glucanase and breaks down the cell walls of pathogenic fungi [15].

Trichoderma species are cosmopolitan fungi frequently present in all types of soil, manure, and decaying plant tissue [5].

The fungus Trichoderma citrinoviride, is a widespread soil fungus of the longibrachiatum clade in the genus Trichoderma. T. citrinoviride is one of the most common species of Trichoderma communities isolated from soil [16].

Published on December 31, 2020

Ariunjargal Jargalsaikhan, Institute of Plant Protection, Mongolia.

(e-mail: ariunjargal0327@ gmail.com)

Temuujin Janchiv, Institute of Plant Protection, Mongolia.

(e-mail: temet9000@gmail.com)

Gantuya Myagmarsaikhan, Institute of Plant Protection, Mongolia.

(e-mail: gana_1206@yahoo.com)
Trichoderma spp. are also used as BCAs against plant pathogenic fungi such as B. cinerea, Fusarium spp., Pythium spp., and Rhizoctonia spp [16].

Endophyte fungus $T$. citrinoviride is a highly active biocontrol agent against ginseng disease [12].

Trichoderma is effective in breaking down soil compounds and improving plant growth and soil nutrients. Trichoderma fungal spores are used for watering, spraying the leaves during transplanting, and before and after treatment. Trichoderma-based products are marketed worldwide and are used to control soil pathogens such as Pythium and Rhizoctonia in farms, nurseries and gardens [6].

Using this beneficial fungus, it is possible to develop and introduce a technology for the production of biofungicide for the control of fungal pathogens in greenhouse crops.

\section{MATERIALS AND Methodology}

\section{A. Soil Samples}

Taken from 0-20 cm deep soil in golf course, Bogd mountain, Ulaanbaatar city.

\section{B. Method for Isolating Pure Fungal Cultures from Soil}

After diluting the soil sample with up to 10-3 saline solution by Koch reduction dilution method and sterilizing in potato glucose agar (PDA) culture medium, pure culture was isolated by adding 0.03 gr Streptomycin and incubating at $25^{\circ} \mathrm{C}$ for 7 to 10 days, transferring from green and yellowgreen single-cell colonies to potato glucose agar (PDA) medium and incubating at $25^{\circ} \mathrm{C}$ for $7-10$ days.

\section{ITS Sequencing and Phylogenetic Analysis}

Fungal DNA was isolated using the CTAB buffer method. The polymerase chain reaction amplified the DNA control portion of the genome. ITS15'TCCGTFGGTGFFCCTGCGG and ITS45'TCCTCCGCTTATTGATATGC primers were used in the gDNA control zone to identify the fungal species. The total PCR reagent is calculated at $50 \mu \mathrm{l}, 5 \mu \mathrm{l}$ of $10 \mathrm{x}$ Dream buffer, $1 \mu \mathrm{l}$ of dNTP, $1 \mu \mathrm{l}$ of each primer, $3 \mu \mathrm{l}$ of sample, $1 \mu \mathrm{l}$ of polymerase (Dream taq polymerase), was dissolved in $39 \mu \mathrm{l}$ of ultra-sterile water (Thermofischer Oltrapure), predenation of the reaction conditions at $94{ }^{\circ} \mathrm{C}$ for $5 \mathrm{~min}, 35$ cycles: 30 sec at $94{ }^{\circ} \mathrm{C}, 30 \mathrm{sec}$ at $58{ }^{\circ} \mathrm{C}, 30 \mathrm{sec}$ at $72{ }^{\circ} \mathrm{C}$, and multiplied

Esentaish Gantsolmon, Institute of Plant Protection, Mongolia. (e-mail: esenka95@yahoo.com)

Otgonjargal Khureldagva, Institute of Plant Protection, Mongolia. (corresponding e-mail: otgooo0529@yahoo.com) 
by configuring for $7 \mathrm{~min}$ at $72{ }^{\circ} \mathrm{C}$ for the final lengthening step (My Genie TM 32 Thermal Block, Bioneer). The PCR generated product was tested by $1.5 \%$ agarose gel electrophoresis. PCR results were calculated revealing 1,500 $\mathrm{XH}$ gel and further study on PCR gene sequence identification study was conducted at Macrogen in the Republic of Korea, compared with a sequence registered with Genbank (NSBI), identified genetic relationship and determined the species.

\section{Determination of Antagonistic Activity}

a) Culturing pathogen: Three pathogens, such as Alternaria alternata, Cladosporium fulvum, and Fusarium oxysporium, were incubated in potato glucose agar (PDA) medium at $25^{\circ} \mathrm{C}$ for 7 to 10 days.

b) Culturing antagonistic fungal: Trichoderma fungal culture was inoculated on potato glucose agar medium at $7{ }^{\circ} \mathrm{C}$ for 7-10 days.

c) Determining antagonistic activity: Potato glucose agar (PDA) is drilled into an agar slice (approximately $6-8 \mathrm{~mm}$ in diameter) in a culture medium with sterile instruments from pathogenic fungi and Trichoderma cultures. Placed one slice of the pathogen and 1 slice of Trichoderma in a Petri dish, incubated at $25^{\circ} \mathrm{C}$ for $7-14$ days, and the antagonistic activity was determined by dominating colony by the following formula:

$$
\frac{\mathrm{R} 1-R 2}{R 1} x 100=\%,
$$

where

$\mathrm{R} 1$ - The diameter of the fungus grown in the control dish. $\mathrm{R} 2$ - The diameter of the fungus grown in Petri dish with Trichoderma.

\section{E. Determining Biological Activity against Tomato alternariosis}

\section{a) Culturing Alternaria alternata}

The plant pathogen Alternaria alternata was incubated in PDA medium at $25{ }^{\circ} \mathrm{C}$ for 10 days, washed with a $0.1 \%$ solution of Twin- 80 and $10^{5}$ spores suspension was prepared.

\section{b) Infecting tomato with Alternaria alternata}

When the tomatoes have 5-6 leaves, it was infected by spraying $30-40 \mathrm{ml}$ spore suspension $/ 10^{5} /$ per plant. To make the infection more effective, it is covered with a plastic bag for 24-48 hours after infection, and the symptoms appeared within a week.

\section{c) Determining biological activity}

When planting tomato seedlings in pots, cultures of antagonistic active fungi around the roots were irrigated with $10^{8}, 10^{9}$ spores / $\mathrm{ml}$ to $50 \mathrm{ml}$. The antagonist culture was tested with 2 doses of $10^{8}, 10^{9}$ spores $/ \mathrm{ml}$ and 3 repetitions when the degree of disease of artificially infected tomato leaves was 1 point. There should be at least 5 tomatoes per repetition, and $30-40 \mathrm{ml}$ of culture was sprayed per plant twice at 7-day intervals. Biological activity was determined by assessing disease progress and degree at 7, 14, and 21 days and comparing with control plants.

\section{d) Methodology for plant disease detection}

Detection of plant disease degree is completed by determining the percentage of diseased part (spot, stain etc.) of the plant on the total surface area the plant. The severity of the disease is expressed in points. Usually a 5-point classification is used. A score of 1-2 indicates low morbidity, a score of 3 indicates an increase in morbidity, and a score close to 4 indicates epiphytotic. 0 point means no disease symptom on plant.

The degree of plant disease is determined by a score of 0 5 , and the progress or index of plant disease is determined by the average degree of plant disease.

$$
P x=\frac{\sum(\mathrm{axb})}{\mathrm{nxk}} \times 100 \%
$$

where

Px - progress of plant disease, $\%$.

a - quantity of diseased plant.

$\mathrm{b}$ - disease/sickness rate, score.

$\mathrm{n}$ - quantity of plants taken for calculation.

$\kappa$-the highest score of plant disease rate.

Biological activity of biopreparation has been calculated by using Abbott formula.

$$
\ni=\frac{(\mathrm{k}-0) \times 100}{\mathrm{k}}
$$

where

$\ni$ - biological activity, \%.

$\kappa$ - disease progress of plant under the control, $\%$.

0 - disease progress in version processed by biological preparation, $\%$.

\section{F. Jasmonic Acid Research}

After the above biological activity determination test, $2 \mathrm{~g}$ sample was taken from each plant treated with $10^{9}$ and $10^{8}$ cells/ml of Trichoderma citrinoviride 31/4 culture, diseased control, healthy control, ground it, put in a tube with $10 \mathrm{ml}$ solution (95\% methanol: 5\% ethyl acetate) and mixed with the vortex for 15 seconds. After that centrifuged at 13,000 rpm for 10 minutes, the supernatant was separated, filtered through a $0.45 \mu \mathrm{m}$ nylon membrane, and placed in a glass jar.

\section{GC-MS Conditions}

CLARUS SQ 8 GC / MS equipment is adjusted as follows using RxiR-5ms type $30 \mathrm{~m}$ long, $0.25 \mathrm{~mm}$ diameter I.D. Using the $\mathrm{x} 0.25 \mu \mathrm{m}$ column. Detector temperature is $280^{\circ} \mathrm{C}$, Source temperature is $240^{\circ} \mathrm{C}$, Injector temperature is $250^{\circ} \mathrm{C}$, Carrier gas helium is $1 \mathrm{ml} / \mathrm{min}$, Split total flow is $20 \mathrm{ml} / \mathrm{min}$, Injection volume is $0,2 \mu$ л.

\section{Mass Spectrometer Adjustment}

Detector mass range $-45-480 \mathrm{~g}$.

Gas Chromatograph Adjustment.

Keep the gas chromatograph oven temperature at $40{ }^{\circ} \mathrm{C}$ for $3 \mathrm{~min}$. Then increase the temperature to $150^{\circ} \mathrm{C}$ at $20^{\circ} \mathrm{C} / \mathrm{min}$ speed. Then increase the temperature to $280{ }^{\circ} \mathrm{C}$ at $10^{\circ} \mathrm{C} / \mathrm{min}$ speed and finish the analysis by keeping the temperature at $280{ }^{\circ} \mathrm{C}$ for $6.5 \mathrm{~min}$.

\section{RESUlts}

\section{A. Isolation of Pure Trichoderma Cultures from Soil}

The soil sample was diluted and cultured in PDA culture to isolate the fungus, and pure cultures similar with Trichoderma in terms of morphology were isolated. 
Trichoderma citrinoviride 31/4 forms a colony with light yellow-green mycelium on the surface of the PDA medium, with spherical spore, septate hyphae, branched conidophores.

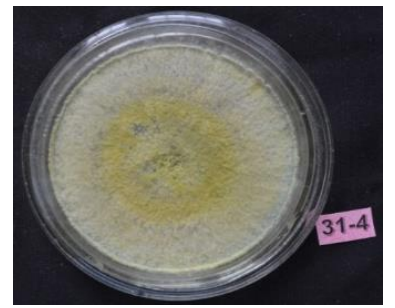

Fig. 1. Pure culture of Trichoderma citrinoviride 31/4 /under PDA medium/.

\section{B. ITS Sequencing and Phylogenetic Analysis}

The DNA of the culture was isolated by the CTAB buffer method, and the sequence was determined using ITS15'TCCGTFGGTGFFCCTGCGG and ITS45'TCCTCCGCTTATTGATATGC primers, and the multiplying DNA.

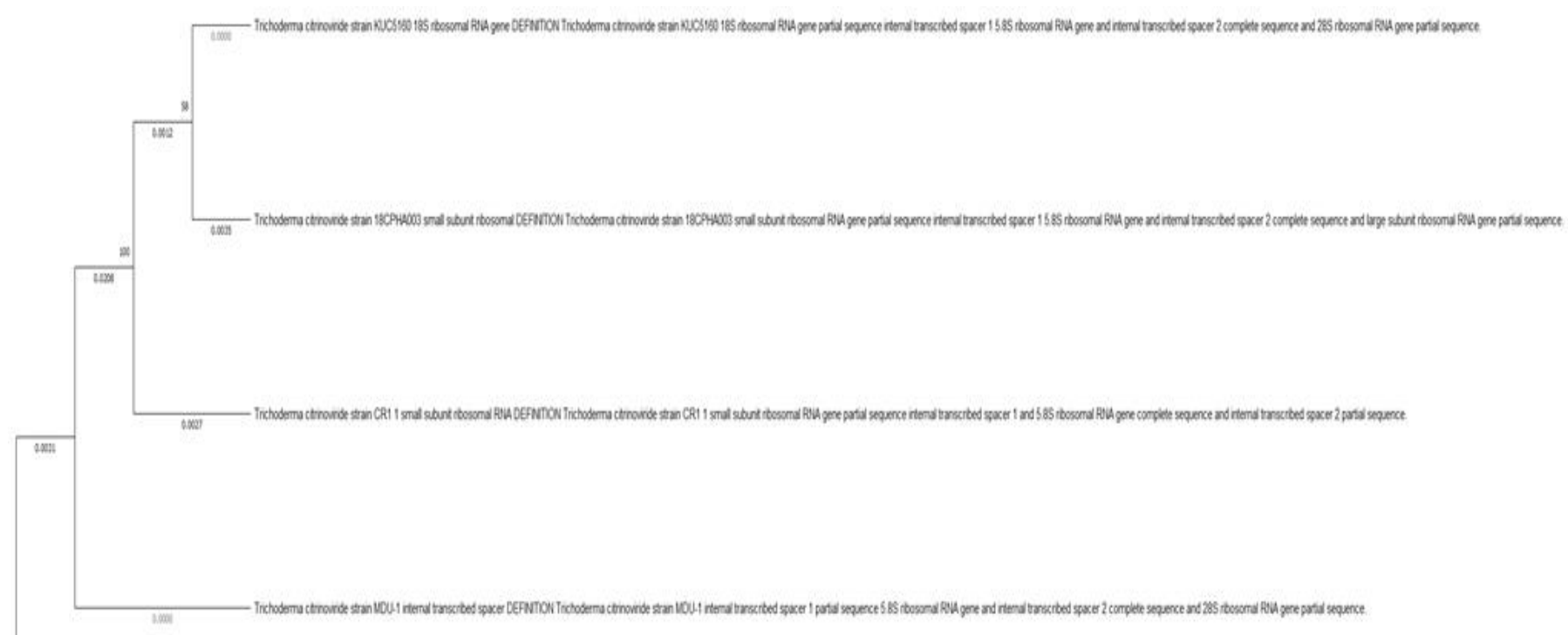

The development history was determined by using the Neighbor-Joining method. The optimal tree with the sum of branch length $=0.05975663$ is shown. Next to the branches, there is the percentage of replicate trees in which the associated taxa clustered together in the bootstrap test $(500$ replicates). The evolutionary distances were computed by using the Tamura-Nei method and are in the units of the number of base substitutions per area. This analysis covered 5 nucleotide sequences. Codon positions included were $1 \mathrm{st}+2 \mathrm{nd}+3 \mathrm{rd}+$ Noncoding. All ambiguous positions were removed for each sequence pair (pairwise deletion option). There were total of 1358 positions in the final dataset. Development analyses were conducted in MEGA X.

\section{Antagonist Activity}

To determine antagonist activity of Trichoderma citrinoviride $31 / 4$ isolated from soil, it was tested on plant pathogens such as Alternaria alternata, Cladosporium fulvum, and Fusarium oxysporium by double culture method. The pathogen and the studied actinomycetes were incubated in potato glucose agar medium with 4 repetitions at $25^{\circ} \mathrm{C}$ for 7 days and the diameter of the pathogenic fungal colony was measured and compared with the diameter of the pathogen grown in the control dish.
TABLE 1: ANTAGONIST ACTIVITY OF TRICHODERMA CITRINOVIRIDE 31/4

\begin{tabular}{|c|c|c|c|c|}
\hline \multirow[b]{2}{*}{ Variants } & \multicolumn{4}{|c|}{ Antagonist activity (\%) } \\
\hline & $\begin{array}{c}\text { Alternaria } \\
\text { alternata }\end{array}$ & $\begin{array}{l}\text { Cladosporium } \\
\text { fulvum }\end{array}$ & $\begin{array}{l}\text { Fusarium } \\
\text { oxysporum }\end{array}$ & $\begin{array}{l}\text { Ave- } \\
\text { rage }\end{array}$ \\
\hline & 77.5 & 66.7 & 59.1 & \\
\hline $\begin{array}{c}\text { Trichoderma } \\
\text { citrinoviride } \\
31 / 4\end{array}$ & & & 4 & 67.8 \\
\hline $\begin{array}{l}\text { Pathogen } \\
\text { control }\end{array}$ & & & & - \\
\hline
\end{tabular}

According to the above study, Trichoderma citrinoviride $31 / 4$ had $66.7 \%$ antagonist activity against Cladosporium fulvum, $77.5 \%$ against Alternaria alternata, and $59.1 \%$ against Fusarium oxysporium after 7 days.

\section{Biological Activity of Trichoderma citrinoviride 31/4} against Tomato alternariosis

After growing tomatoes in a greenhouse and artificially infecting with the pathogen Alternaria alternata, $10^{9}, 10^{8}$ 
spores suspension of Trichoderma citrinoviride 31/4 were sprayed twice at 10-day intervals and biological activity was determined after 21 days.

Tomatoes began to get sick a week after being infected with the pathogen alternariosis.

The results of the study showed that the development of tomato disease treated with $1.2 * 10^{9}$ spores $/ \mathrm{ml}$ suspension of
Trichoderma citrinoviride 31/4 was reduced by $49-52 \%$ in 21 days compared with the control variant.

Experimental results showed that the course of tomato alternariosis treated with Trichoderma citrinoviride 31/4 was neutralized from the 7 th day, and the biological activity was averagely $74 \%$ on the 21 st day.

TABLE 2: BIOLOGICAL ACTIVITY OF TRICHODERMA CITRINOVIRIDE 31/4 / ALTERNARIA ALTERNATA/

\begin{tabular}{|c|c|c|c|c|c|c|c|c|c|c|c|c|}
\hline \multirow{3}{*}{ № } & \multirow{3}{*}{$\begin{array}{l}\text { Antagonist } \\
\text { strain }\end{array}$} & \multirow{3}{*}{ Variant } & \multirow{3}{*}{ Repeat } & \multicolumn{4}{|c|}{2019} & \multicolumn{4}{|c|}{2020} & \multirow{3}{*}{$\begin{array}{c}\text { Biological } \\
\text { activity } \\
\text { /average } \% /\end{array}$} \\
\hline & & & & \multicolumn{3}{|c|}{ Disease progress $\%$} & \multirow{2}{*}{$\begin{array}{l}\text { Biological } \\
\text { activity \% }\end{array}$} & \multicolumn{3}{|c|}{ Disease progress $\%$} & \multirow{2}{*}{$\begin{array}{l}\text { Biological } \\
\text { activity } \%\end{array}$} & \\
\hline & & & & $\begin{array}{l}7^{\text {th }} \\
\text { day }\end{array}$ & $14^{\text {th }}$ day & $\begin{array}{l}21^{\text {th }} \\
\text { day }\end{array}$ & & $\begin{array}{l}7^{\text {th }} \\
\text { day }\end{array}$ & $\begin{array}{l}14^{\text {th }} \\
\text { day }\end{array}$ & $\begin{array}{l}21^{\text {th }} \\
\text { day }\end{array}$ & & \\
\hline 1. & \multirow{3}{*}{$\begin{array}{c}\text { Trichoderma } \\
\text { citrinoviride } \\
31-4\end{array}$} & Хяналт & 3 & 24.6 & 30 & 64.6 & - & 49.3 & 60 & 72 & - & - \\
\hline 2. & & $1 * 10^{8}$ & 3 & 18.6 & 20 & 22.6 & 65.0 & 22.7 & 26.6 & 22.6 & 68.6 & 66.8 \\
\hline 3. & & $1.2 * 10^{9}$ & 3 & 12 & 13.3 & 15.3 & 76.3 & 18.7 & 21.3 & 20 & 71.7 & 74 \\
\hline
\end{tabular}

\section{E. Results Determined Jasmonic Acid}

After the above tomato experiment, $2 \mathrm{~g}$ sample was taken the plant and tested for jasmonic acid. Jasmonic acid is a compound that represents the plant disease resistance.

When the sample was read on a GC/MS instrument, the peak of the standard substance was observed at 13.22 minutes, and when the peak of the standard substance was compared with that of the sample, peak was observed at 13.03 and 13.01 minutes on plant samples treated with Trichoderma citrinoviride $31 / 4$ culture, proving existence of jasmonic acid. Jasmonic acid was not found in diseased and healthy control plants, and plant treated with $10^{9}$ spores/ml Trichoderma citrinoviride $31 / 4$ culture contained $0.0135 \mathrm{mg} / \mathrm{kg}$ jasmonic acid, plant treated with $10^{8}$ spores $/ \mathrm{ml}$ contained $0.0076 \mathrm{mg} / \mathrm{kg}$ jasmonic acid. Experiments have shown that treatment with Trichoderma citrinoviride $31 / 4$ cultures forms the resistance of tomatoes to alternariosis.

TABLE 3: SAMPLING OF THE JASMONIC ACID CONTENT IN THE GC/MS DEVICE

\begin{tabular}{ccc}
\hline $\begin{array}{c}\text { GC/MS } \\
\text { Sample } \\
\text { number }\end{array}$ & Sample name & $\begin{array}{c}\text { Jasmonic acid } \\
\mathrm{mg} / \mathrm{kg}\end{array}$ \\
\hline Ja 4 & $\begin{array}{c}\text { Plant treated with } 10^{9} \text { cell/ } / \mathrm{ml} \\
\text { Trichoderma citrinoviride } 31 / 4 \\
\text { Plant treated with } 10^{8} \mathrm{cell} / \mathrm{ml}\end{array}$ & 0.0135 \\
Ja 3 & $\begin{array}{c}\text { Trichoderma citrinoviride } 31 / 4 \\
\text { Diseased control }\end{array}$ & 0.0076 \\
Ja 15 & $\begin{array}{c}\text { Healthy control } \\
\text { Ja } 14\end{array}$ & 0 \\
Ja & Jasmonic acid standart & 0 \\
\hline
\end{tabular}
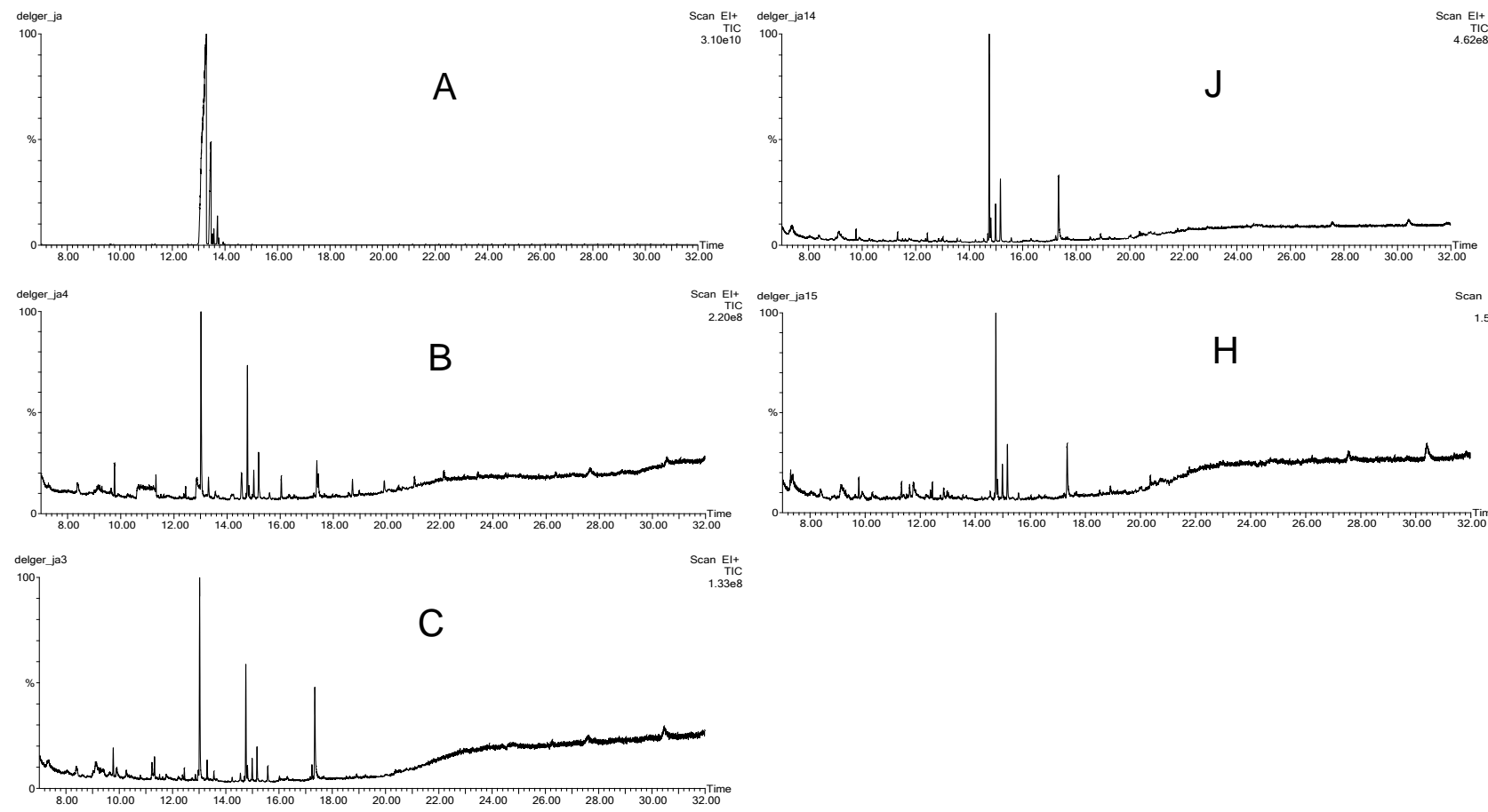

Fig 3. A. Jasmonic acis standard, B. Plant treated with $10^{8}$ cell $/ \mathrm{ml}$ T.citrinoviride $31 / 4$ culture, C. Plant treated with $10^{9}$ cell $/ \mathrm{ml}$ T.citrinoviride $31 / 4$ culture, D., J- Healthy control, H- Diseased control. 


\section{REFERENCES}

[1] H. L. Barnett., Barry. B. Hunter., Illustrated of genera imperfect Fungi.

[2] Rifai, M.A. Mycological Papers 116: 27., 1969.

[3] Samuels, Gary J., "Trichoderma: Systematics, the Sexual State, and Ecology" 2006.

[4] Отгонжаргал. Х бусад "Хөрсний бичил биетний судалгаа, ургамал хамгаалалд хэрэглэх боломж” ССТөслийн арга зүй.

[5] Ahsanur Rahman., M.A.Bari., Isolation and identification of Trichoderma species from different habitats and their use for bioconversion of solid waste., 2009.

[6] M. M. Shah., Hamisu Afiya., Identification and Isolation of T richoderma spp. - Their Significance in Agriculture, Human Health, Industrial and Environmental Application.

[7] M. Khandelwal., Subhas Chandra., Isolation, characterization \& biomass production of Trichoderma viride using various agro productsA biocontrol agent. 2012.

[8] M. Kushwaha., A. J. Kumar., Antagonistic Activity of Trichoderma Spp, (A Bio-Control Agent) Against Isolated and Identified Plant Pathogens. 2014.

[9] A potential bio control agent for soil borne diseases in the Islands. 2016.

[10] Ghildyal, A., Pandey, A., "Isolation of cold tolerant antifungal strains of Trichoderma sp. from glacial sites of Indian Nimalayan Region," Research Journal of Microbiology, Vol.3(8), pp.559-64., 2008.

[11] Young-HwanPark et al. Endophytic Trichoderma citrinoviride isolated from mountain-cultivated ginseng (Panax ginseng) has great potential as a biocontrol agent against ginseng pathogens.

[12] Ubalua, A., Oti, E., "Antagonistic properties of Trichoderma viride on post harvest cassava root rot pathogens," African Journal of Biotechnology, Vol.6, (21), pp.2447-450.

[13] Kayim M, Yones A. M., Endes A, Biocontrol of Alternaria alternata causing leaf spot., 2007. disease on faba bean (Vicia faba L.) using some Trichoderma harzianum 1solates under in vitro condition., 2017.

[14] https://en.wikipedia.org/wiki/Trichoderma.

[15] https://mycocosm.jgi.doe.gov/Trici1/Trici1.home.html. 